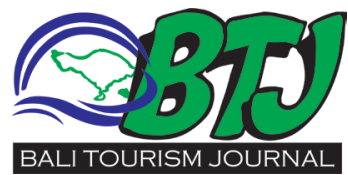

\section{The Agrarian Tale of Kenderan Village: Sarcophagus, a Magical Priest, and Farming Sciences}

Ida Bagus Putra Setiawan

\section{ABSTRACT}

In discussing Bali's agricultural history development, the name of Kenderan village would occasionally appear. It is one of many villages that inherited subak tradition from ancient times. The town, located in Tegalalang district, Gianyar, has witnessed the growth of farming customs on the island of the gods. The people of the kenderan village have been an agricultural society since the megalithic period around $4500-1500$ BC. It is proved by the Sarcophagus around the village and the bronze nekara printing similar to Nekara in Pejeng. These remnants signed that there was a settlement with high cultural society. Nekara was used as a drum to summon rain related to agricultural practice. Further, after Padanda Sakti Manuaba's arrival, the society was introduced to a water reservoir system, dam, and rituals needed to support the farm's sustainability. The community keeps the tradition and rituals as part of their identity up to the moment. Every year, through a distinctive ritual, 'nyawang,' they express their gratitude to God for a long, lush, fertile and prosperous life.

*Sanur Village Community; ibsetiawan@gmail.com

Received: 2021-05-21

Accepted: 2021-07-28

Published: 2021-08-10

Keywords: Kenderan Village, Agriculture, Ritual.

Cite This Article: Setiawan, I.B.P. 2021. The Agrarian Tale of Kenderan Village: Sarcophagus, a Magical Priest, and Farming Sciences. Bali Tourism Journal 5(2): 41-44. DOl: 10.36675/btj.v5i2.60

\section{INTRODUCTION}

In discussing Bali's agricultural history development, the name of Kenderan village would occasionally appear. It is one of many villages that inherited subak tradition from ancient times. The town, located in Tegalalang district, Gianyar, has witnessed the growth of farming customs on the island of the gods. Old remnants such as sarcophagus and copper artifacts around the village showed that agricultural activity had been going on from the megalithic era to the metal age (4500-1500 BC). According to the village elders, the farming method was perfected when a holy priest came to settle. In the seventeenth century, during King Dalem Dimade reigned, A priest named Pedanda Sakti Buruan, better known as Pedanda Sakti Manuaba, secured the position of the Kenderan village as the highest traditional agricultural society in Bali. He also passed his knowledge in farming as written in the lontar dharma pemaculan. Today, the scripture still serves as a reference for Balinese farmers in choosing a good day or ceremonies needed to start agricultural activities.

\section{Indraloka on Earth}

Located 600 meters above sea level, Kenderan Village has a relatively flat land surface/landscape. With an average humidity of $80 \%$, this land has been used as agricultural sites, holy places, graves,

public roads, schools, and residences. The village has a tropical climate with a minimum temperature of $22^{\circ} \mathrm{C}$ and a maximum of $28^{\circ} \mathrm{C}$. Kedisan Village borders Kenderan Village in the North. Sanding Village is the eastern boundary,

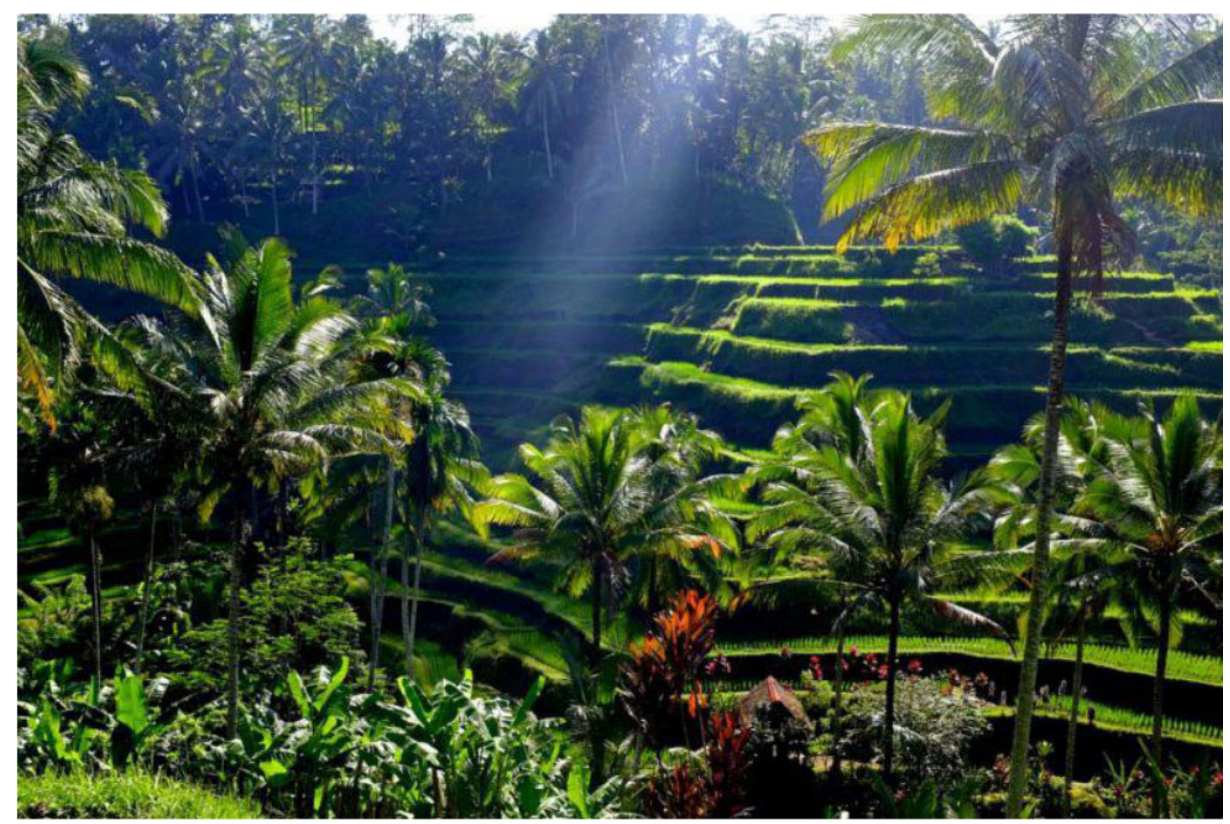

Figure 1. ${ }^{1}$ Ricefield in Kenderan Village. The village's geographical location, fertility and beauty are often compared to Lord Indra's palace in Indraloka. 

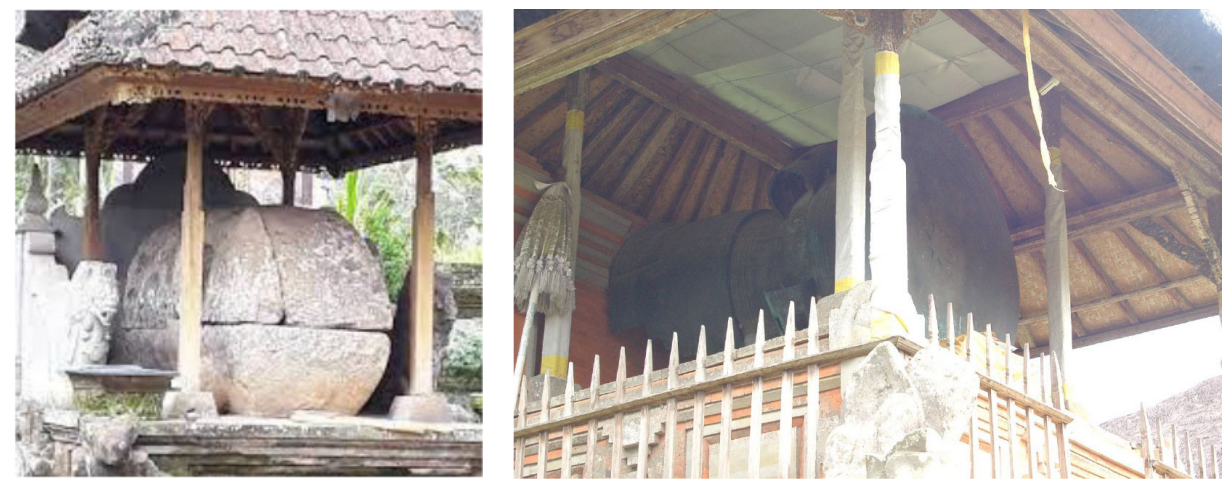

Figure 2 \& 3.4 a Sarcophagus in Manuaba and Nekara in Penataran Sasih Temple, Pejeng, Gianyar.

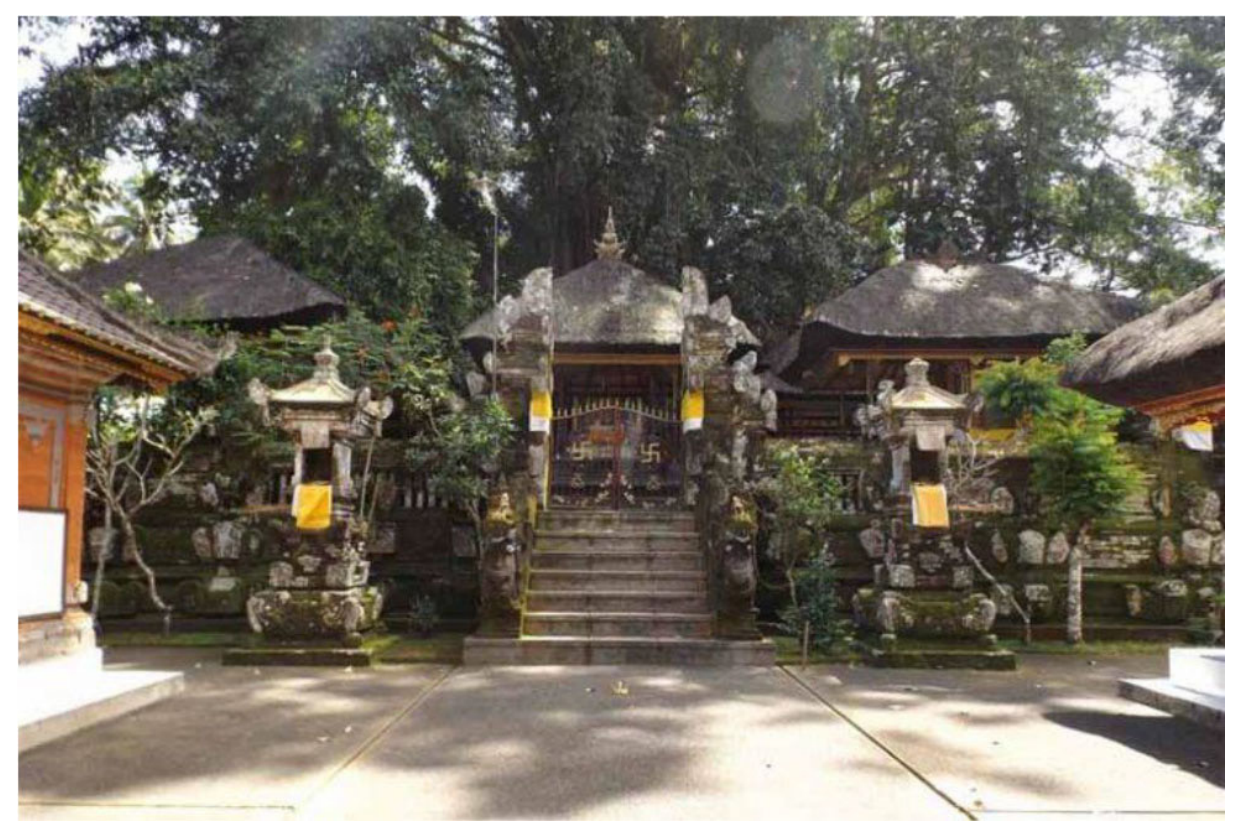

Figure 4. ${ }^{8}$ Pura Griya Sakti Manuaba was a residence of Peranda Sakti Buruan. He was the son of Peranda Ketut Ler, and the Grandson of Dang Hyang Nirartha, an influential figure in Balinese History.

while Tegalalang village is its western and southern boundary. The area is led by a Perbekel and consists of ten official banjars and three Traditional Villages. The Banjar Dinas in Kenderan Village are Banjar Dlod Blungbang, Banjar Pande, Banjar Tangkas, Banjar Tengah, Banjar Triwangsa, Banjar Gunaksa, Banjar Pinjul, Banjar Dukuh, Banjar Kenderan, and Banjar Kepitu. As for the Traditional Village itself, Kenderan Village consists of three traditional villages: the Dlod Blungbang Traditional Village, the Manuaba Traditional Village, and the Kenderan Traditional Village.

The Kenderan Village's settlement pattern is based on the Tri Hita Karana concept, which consists of parahyangan (praying area), pawongan (housing/ settlement area) and palemahan (plantation and livestock area). They believed that organizing the site would lead to a harmonious ambiance with nature. According to legend, The village of Kenderan is derived from the word Ke-Indra-an. The people often call it the "Palace of Lord Indra" due to the mythology of the local community. Long ago, their ancestors were refugees from the tyranny of King Mayadenawa in the $6^{\text {th }}$ century. Based on the community's belief, the symbol of Lord Indra has been used as the village sigil. Due to the community's strong faith, they even describe The village's geographical location, fertility, and beauty compared to Lord Indra's palace in Indraloka.

There are two important sites that relate to the historical process of Kenderan Village. The locations are Petirtaan Telaga Waja and Manuaba Village. Some archaeologists believe the Manuaba area was part of an ancient settlement. In the Manuaba Village area, two Sarcophagus were found in Subak Uma Lawas. Furthermore, at Puseh Temple in Manuaba Village, there are several pieces of bronze Nekara printing equipment. Imaginative reconstructions of this discovery suggest that this printing press is related to the bronze nekara at Penataran Sasih Temple in Pejeng Village. ${ }^{2}$ Nekara or Dong Son drums or Heger Type I drums is a bronzemade drum introduced by Dong Sun Culture. This important relic is thought to have been created around 600 years BC to the 3 rd century AD. the shape resembles a metal or bronze sound membrane with a waistcoat in the middle.

This one of the finest pieces of evidence of metalworking was generally used as a musical instrument in sacred ceremonies or festivals, for example, in the rain calling ceremony, for celebrations or harvest ceremonies, to support wedding ceremonies and funeral ceremonies. In Battle, Nekara would be pounded as a war drum to support the troops in the war. ${ }^{3}$ Besides its primary function as a musical instrument, the relic also served as the tribal chief's symbol of strength, a mausoleum, and offering for the dead. In Indonesia, Nekara was only functioned as rain nekara. The motifs found on the bronze work displayed shamans or sometimes disguised as horned beasts.

The Petirtaan Telaga Waja provided clues that the place was once a hermitage. The presence of alcoves for meditation, niches for resting, showers and holy water sprouts are some of the remnants that can be seen at the moment. On the niche's entrance, there is a relief of letters. The relief indicates that the western edge of Kenderan Village has been served as a navel of religious activities. Since the $10^{\text {th }}$ century, the action has had a strong influence on the culture of the people of Kenderan Village. Then In the seventeenth century, during the reign of Dalem Dimade in Gelgel, there had come to the village a 


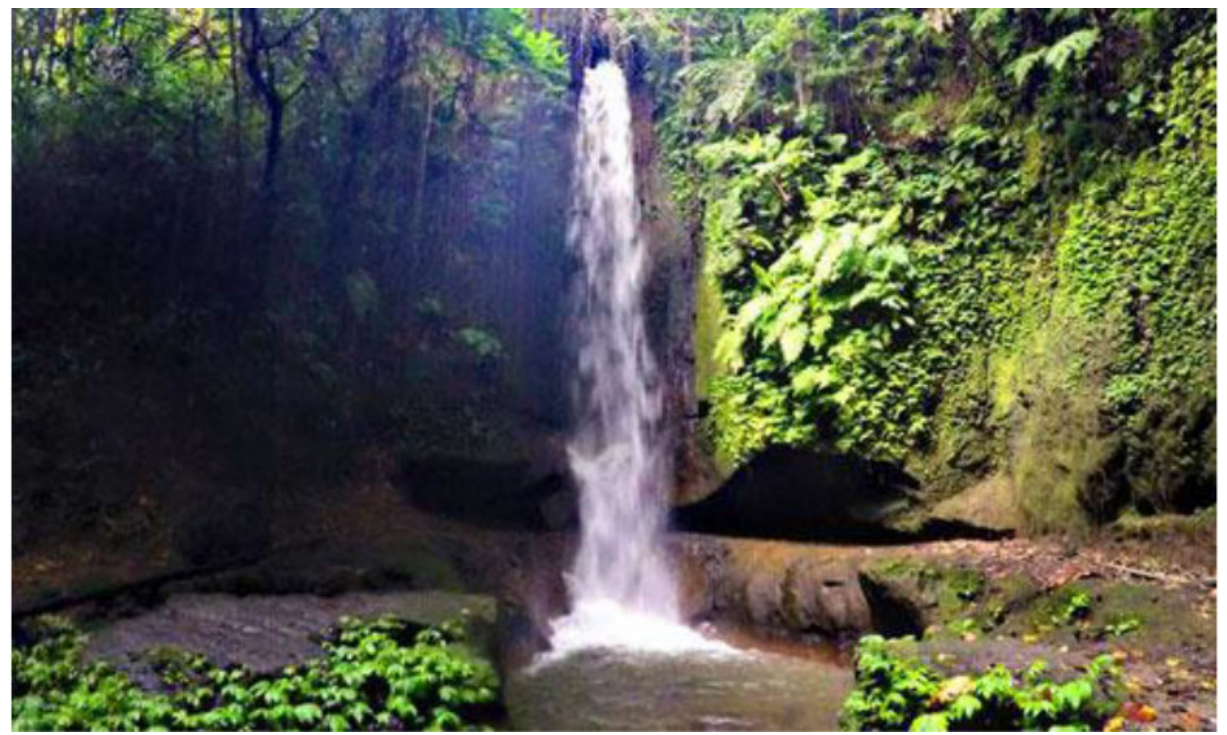

Figure 5. ${ }^{13}$ Manuaba Waterfall.

priest named Pedanda Sakti Buruan. In folklore, He was a priest who devoted his life to religious practice (Kadyatmikaan) and social service that significantly affected the social life at the time. His legacy in Manuaba Village is a temple, a dam and an Agricultural manual, known as Lontar Dharma Pemaculan. ${ }^{5,6}$

\section{The Gria Sakti Manuaba Temple}

Gria Sakti Manuaba temple was a residence of Peranda Sakti Buruan. He was the son of Peranda Ketut Ler, and the Grandson of Dang Hyang Nirartha, an influential figure in Balinese History. After his deceased, the residence was transformed into temple by the local residents. Today, The Griya Sakti Manuaba Temple in Pakraman Manuaba Village, Kenderan Village, Tegallalang Gianyar, is hosted by seven traditional banjars, namely Banjar Pande, Tangkas, Tengah, Triwangsa, Gunaksa, Pinjul, and Banjar Dukuh. Although initially, Griya Sakti Manuaba Temple is a Kawitan Temple for the Manuaba clan, but now the status of the temple is Khayangan Jagat Temple.

Griya Sakti Manuaba Temple consists of three mandalas. There is a quite large open building in the outer Mandala to host a large meeting or preparation site when the temple conducts a ceremony. Not far from wantilan, there is a small giant with a tiger statue in the middle. In the Main Mandala courtyard, there are several small shrines. Ten days after Kuningan Day, or on Tuesday Kliwon Medangsia, according to the Balinese calendar, the temple celebrated its annual ceremony. The temple would be packed with pilgrims, not only from Manuaba clan descendants or residents pilgrims from all over Bali would come to pray. ${ }^{7}$

During Dalem Dimade reign, it was said that the local community had experienced a long drought and disease outbreaks. The eternal suffering led the people to pledge to King Dalem. The King then appointed Peranda Ketut Ler, the kingdom's high priest, to help the community in Pakraman Manuaba Village. The high priest with I Gede Bawa and his son I Ketut Tangsub made various efforts to end the disaster.

Thanks to his supernatural powers, the village and the surrounding area became prosperous and free from disease. From that moment, he continued to help many problems in society; He cured many people's sicknesses without medicine. Thus, from that moment, he has been known as Peranda Sakti Manuaba.

The people of Manuaba then asked him to settle down and live in Manuaba Village to protect and save Manuaba Village. The community's request was fulfilled; he was willing to reside in Manuaba Village with I Ketut Tangsub. Another legend was his ability to create a water spring from a scoop of water. The water spring is known as Manuaba Waterfall. The water then collected in the dam, making the village fertile and prosperous. In addition to making dams, he also imparted his knowledge in agriculture, which can be seen in the Lontar Dharma Pemaculan. However, a few years later, a district head named Gusti Batu Lepang decided to attack and destroy the priest's settlement in Manuaba. The priest disappeared after the battle while his wife, sons, and grandchildren escaped to the east. ${ }^{9,10}$

\section{Agricultural Manual in Dharma Pemaculan Text}

From ancient times, the agricultural sector has been vital for the life of Balinese society. Amid the onslaught of modern times, agriculture in Bali still exists. Especially in rural areas, conducting a series of ceremonies to get good harvests has been done today. The traditional customs, including its tutorials and agriculture philosophies, are discussed in Lontar Dharma Pemaculan. At the beginning of the script, The text states, "it would be wise for humans to harmonize their work and achievement with nature as the holder of the Almighty's mandate." Humans were very aware that their lives were blessed by nature in the past. Thus, humans always ask for nature's permission before doing something. Likewise, they also reported it to the universe after they completed it.

The manuscript further discussed the ceremony for subak in Bali, offerings and mantras. Other provisions such as planting rice, and harvesting, should be adjusted with certain days to achieve success. ${ }^{11}$ Dharma Pemaculan text discusses several deities in Besakih, Batur, Uluwatu, and others. Finally, Sang Baka Bhumi resided in Ulun Swi as a source of life in the fields. According to the written decree, should the offering for Ulun Swi deities be stopped, the harvest would significantly decrease due to the earth's essence having returned to the monks at Mount Agung and Batur. There would be many diseases, drought and misery await. One of the special ceremonies written on the lontar is the rasakin ceremony. This ceremony is preceded by making a sanggah tutuan in the rice fields. The banten placed in the tutuan sanggah are peek adanan lakah a besik, daksina dadua, and jrimpen. For the lower part offerings are sesayut pengambean, peras penyeneng, lis dan bija 
kuning, a pair of grasak duck.

According to the researcher from Gedong Krtya Museum, the content of Dharma Pemaculan is related to several agricultural manuscripts, such as Lontar Aji Pari, Lontar Pesesawahan, and Lontar Sri Purana Tatwa. Based on the content of Aji Pari's Lontar, 'Bhatara Sri came from Kamulan' (East Java). It can be interpreted that the rice seeds in Bali came from Java during the Airlangga reigned (11 $1^{\text {th }}$ century) or might be earlier. Perhaps there was a rice species native to Bali. However, a better rice species in East Java was later preferred in Bali. ${ }^{12}$ Together, Lontar Dharma Pemaculan, Aji Pari, Pesesawahan and Sri Purana tatwa have been used as the principal knowledge for traditional farmers to cultivate crops, choose good seeds, ceremonies in the rice fields, and agricultural-related matters.

In addition to the remnants of artifacts, sacred sites and agricultural science, The community of Kenderan also has a distinctive agriculture-based tradition that none other traditional villages in Bali have. This tradition is called the nyawang tradition. The tradition results from the waterfall's existence located not far from the hamlet.

There are nine points of water sources in Manuaba Village: Seven springs flow through the rice fields in Subak Manuaba and Kenderan villages. Meanwhile, two water sources flow through Subak Laplapan Ubud. Instead of seven campuhan tirta, there is also a water flow from Campuhan Pitu.

According to residents, waterfalls in Manuaba are different from waterfalls in general. The waterfall in the village is a mixture of several springs. It is said that the seven springs, called tirtha, are mixed on the waterfall. The seven holy springs are called Tirta Sangku, Tirta Sudamala, Tirta Connect Dawa, Tirta Bulan, Tirta Dadapan, Tirta Gringsing and Tirta Lindung Wesi. Therefore, the Manuaba waterfall is believed to emit an aura of holiness, making the holy water also cure several kinds of diseases. Primarily, the water flow supplies for eleven subak in Kenderan Village. The water source is believed to come from Lake Batur, has been told from generation to generation in the legend of Padanda Sakti Manuaba.

As a result of many water sources flowing to Manuaba Village, the communities view it as a gift from God. Therefore, they believe it is essential to perform a ceremony to symbolize gratitude. The locals manifest their appreciation in Nyawang or Mendak Tirta ceremonies. On the day of Nyawang, it is forbidden to close the water flow in the fields or divide the water share. ${ }^{14}$

\section{CONCLUSION}

The people of the kenderan village have been an agricultural society since the megalithic period around 4500-1500 BC. It is proved by the Sarcophagus found around the village and the bronze nekara printing similar to Nekara in Pejeng. These remnants signed that there was a settlement with high cultural society. Nekara was used to summon rain, strongly related to agricultural practice. Further, after Padanda Sakti Manuaba’s arrival, the society was introduced to a water reservoir system, dam, and rituals needed to support the farm's sustainability. The community keeps the tradition and rituals as part of their identity up to the moment. Every year, through a distinctive ritual, 'nyawang,' they express their gratitude to God for a long, lush, fertile and prosperous life.

\section{REFERENCES}

1. Image of alamubudvilla website 'Desa Kendran is Our Village.' 2021. Available at URL: https:// alamubudvilla.com/desa-kendran-is-ourvillage/

2. DWIYANTI, Ni Kadek; ATMADJA, Nengah Bawa; MARGI, I. Ketut. Pura Puseh, Di Desa Pakraman Manuaba, Tegallalang, Gianyar, Bali (Tinjauan Sejarah, Fungsi Pura Dan Potensinya Sebagai Pewarisan Nilai Dalam Pembelajaran IPS Tingkat SMP Berdasarkan Kurikulum 2013). Widya Winayata: Jurnal Pendidikan Sejarah, 2014, 2.3.
3. Wijaya H. Nekara: Peninggalan Seni Budaya dari Zaman Perunggu. Humaniora. 2013 Apr 30;4(1):212-20.

4. Image Collection of Kemdikbud 'Sarchopagus \& Nekara. 2018. Available at URL: http:// kebudayaan.kemdikbud.go.id/bpcbbali/wpcontent/uploads/sites/26/2018/04/PURAPENATARAN-SASIH-19.jpg

5. Indiani NM, Winaja IW, Winantra IK. MODERNISASI DHARMA PEMACULAN DAN IMPLIKASINYA TERHADAP PENDIDIKAN KEAGAMAAN HINDU. Dharmasmrti: Jurnal Ilmu Agama dan Kebudayaan. 2020 Oct 25;20(2):14-20.

6. Adnyawati IA. Land Conversion Versus Subak: How Bali's Face Gradually Changing Throughout History. Bali Tourism Journal. 2019 Nov 30;3(1):38-42.

7. IP Suyatra. Begini Sejarah Pura Griya Sakti Manuaba di Desa Kendran, Tegallalang. Bali Express. 2018. Available at URL: https:// baliexpress.jawapos.com/balinese/29/04/2018/ begini-sejarah-pura-griya-sakti-manuaba-didesa-kendran-tegallalang

8. Image from Bali Headline 'Pura Griya Sakti Manuaba - Desa Kendran'. 2021. Available at URL: https://www.baliheadline.com/puragriya-sakti-manuaba-ada-tradisi-mepeedhindari-bencana/

9. Desa Wisata Kenderan Kabupaten Gianyar, Bali. jadesta. 2021. Available at URL: https:// jadesta.com/desa/20864

10. Ardiyasa IN. Mitigasi Spritual dalam Naskah Lontar Roga Sanghara Bhumi. Sanjiwani: Jurnal Filsafat. 2020 Jul 8;10(1):27-36.

11. IP Suyatra. Lontar Dharma Pemacul; Acuan Petani Bali dalam Bercocok Tanam. Bali Express. 2021. Available at URL: https:// baliexpress.jawapos.com/balinese/18/02/2021/ lontar-dharma-pemacul-acuan-petani-balidalam-bercocok-tanam

12. Novi.Pokdarwis Kenderan Genjot Kunjungan ke Manuaba Waterfall .Nusa Bali .2020. Available at URL: https:/www.nusabali.com/ berita/79687/pokdarwis-kenderan-genjotkunjungan-ke-manuaba-waterfall

13. Image of balitoursclub 'AIR TERJUN MANUABA GIANYAR'. 2021. Available at URL: https://www.balitoursclub.net/air-terjunmanuaba-gianyar/

14. Mahadewi NP, Sudana IP. Model Strategi Pengembangan Desa Wisata Berbasis Masyarakat di Desa Kenderan, Gianyar, Bali. Jurnal Analisis Pariwisata ISSN. 2017;1410:3729.

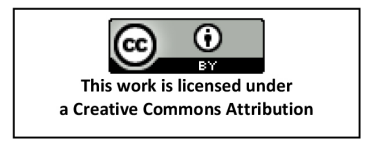

